\title{
Tourism Status and Sources of Income to Local Communities Amidst COVID-19 Pandemic and Its Implications in Biodiversity Conservation in Burunge Wildlife Management Area in Tanzania
}

Francis Chebby ( $\sim$ francismuzaga20@gmail.com )

The University of Dodoma https://orcid.org/0000-0002-9797-3209

Naza Mmbaga

The University of Dodoma

Kelvin Ngongolo

The University of Dodoma

\section{Research}

Keywords: Alternative sources of income, Burunge WMA, COVID-19 pandemic, biodiversity conservation, socio-economic activities

Posted Date: December 21st, 2021

DOI: https://doi.org/10.21203/rs.3.rs-1175273/v1

License: (c) (1) This work is licensed under a Creative Commons Attribution 4.0 International License.

Read Full License 


\section{Abstract}

\section{BACKGROUND}

The COVID-19 pandemic has resulted in various negative repercussions worldwide in terms of biological conservation, the tourism sector and socioeconomic welfare. The purpose of this study was to assess and understand the impact of the COVID-19 outbreak on socio-economic activities, income from the tourism sector, alternative sources of income adapted by the local communities adjacent to the Burunge Wildlife Management Area (WMA) as a means of survival, and its implications for biodiversity conservation. To assess tourism status, socio-economic activities and alternative livelihoods, interviews, semi-structured questionnaires, focus group discussions (FGDs), and key informants' consultations were conducted on 264 respondents, of whom 53\% $(n=140)$ were men and 47\% ( $n=124)$ were women. Secondary data were synthesized from soft and hard copy reports through an extensive literature search in order to comprehend the implications of COVID-19 and alternative livelihoods in biodiversity conservation.

\section{RESULTS}

The results showed that $90.5 \%$ (239) of respondents reported being seriously affected by the emergence of COVID-19, while $9.5 \%(n=25)$ were not affected by it. Some of the impacts of the COVID-19 as pointed out by the respondents included deflation $91.7 \%(n=242)$, a decline in the number of customers $91.7 \%$ ( $n$ = 242), whereas others lost jobs $5.7 \%(n=15)$. In the case of the Burunge WMA authority, revenue collection (mainly from the tourism sector) declined by $32.5 \%$ and $76.4 \%$ for the years $2019 / 20$ and $2020 / 21$, respectively, as compared to the revenue obtained in the year 2018/19 before COVID-19. During the pandemic, local communities adapted to several alternative sources of income, including fishing $9.5 \%$ $(n=25)$, Boda-Boda (motorcycle taxis) 3.4\% $(n=9)$, agriculture $22.3 \%(n=59)$, and livestock keeping $27.3 \%(n=72)$.

\section{CONCLUSION}

Based on the findings of this study, it is important for local communities, especially those adjacent to protected areas, to have diversified means of income that are environmentally and socially sustainable, such as fish farming and beekeeping, to reduce the impacts of unanticipated crises such as COVID-19.

\section{Introduction}

The outbreak of the COVID-19 pandemic is one of the world's greatest shocks. The first instance of Severe Acute Respiratory Syndrome Coronavirus 2 (SARS-CoV-2)-caused sickness was detected in Wuhan, China, in December 2020 (Neupane, 2020). The spread of this virus has become considerably more dangerous, resulting in significant mortality and other health problems not only in Wuhan but also in Hubei Province and other parts of the world (Bennett et al., 2020; Wang et al., 2020) The World Health Organization (WHO) officially declared COVID-19 as a global pandemic on March 11, 2020 (Neupane, 
2020). The global impact of the COVID-19 pandemic has been experienced by each industry. Its effects on the health, ecology, and socioeconomic sectors, to name a few, have disturbed regular patterns of life (Pinner et al., 2020; Saadat et al., 2020). COVID-19 has had a significant impact on the economies of many countries, particularly those on the African continent. According to the UNDP (2020), developing countries are expected to lose approximately 220 billion US dollars as a result of the impact on the operation of various sectors such as education, health, food security, and employment issues, with approximately 3.3 billion people losing their jobs at this time. Many Africans' living conditions have been dubious for years, but COVID-19 has aggravated the situation (World Bank, 2020).

The wildlife sector is not far from the list of industries that have experienced the impact of the COVID-19 pandemic. Some studies have highlighted the benefits of the pandemic on biodiversity conservation, including a reduction in human visitation and pollution within and surrounding protected areas; which appears to maintain natural ecosystems and create a suitable setting for wildlife growth (Bennett et al., 2020; Neupane, 2020). For example, Nepal documented a decrease in carbon emissions and hence air pollution, as well as reduced stress to wildlife due to a decrease in human traffic within the protected and preserved regions (Neupane, 2020). COVID-19's importance in wildlife protection cannot outweigh its negative consequences. The existence of protected and preserved areas was challenged by a decline in donor finances, the failure of numerous development initiatives, and a lack of conservation considerations in government budgets during the crisis. A large portion of the money was diverted to combat and stop the spread of the COVID-19 epidemic (Nyomi, 2020; Rulli, 2020). The imposition of lockdown and travel restrictions was sufficient to demolish all plans and methods for achieving predicted managerial and developmental goals in different areas, including wildlife (AUC, 2020).

Wildlife Management Areas (WMAs) in Tanzania have faced similar issues due to the COVID-19 pandemic (Shoo et al., 2021). Due to the total reliance on tourism activities to manage these places, the occurrence of COVID-19 has had a significant impact on many operations and plans (Kideghesho et al., 2021). The earnings generated by tourism and other investment projects within and around the WMA dwindled. According to Burunge WMA Authority (JUHIBU) leaders, the Burunge WMA, which is the main focus of this research, has faced various obstacles that have slowed the attainment of annual objectives to the point where several activities, including patrols, have been impacted. The effects were felt not just within the protected areas, but also in the surrounding indigenous and local people, which rely fully on this WMA, either directly or indirectly (Shoo et al., 2021; Spenceley et al., 2021). The failure of the market for numerous items, poor demand for produced goods, a dramatic drop in clients, and job loss were among the factors that affected the livelihoods of many people in the WMA (Kideghesho et al., 2021; Manenti et al., 2020).

Despite the availability of information about the implications of the COVID-19 pandemic on protected and conserved areas, as well as recommendations on what should be done to mitigate its effects (Kideghesho et al., 2021; Shoo et al., 2021), very little is known about the degree to which these effects change the patterns and livelihoods of communities, particularly those who rely entirely on protected zones. Furthermore, there is limited data available on the alternative sources of revenue employed by 
local residents adjacent to the protected areas to earn income for their living during the COVID-19 pandemic and its implications for biodiversity conservation (ecological impact). Therefore, there is a need for more extensive studies to explore the aforementioned issues for the well-being of not only protected areas but also local communities adjacent to the protected areas.

The aim of this research was to assess and understand the effects of the COVID-19 pandemic on the tourism industry and the socio-economic activities of local communities around the Burunge WMA. In addition, the study stresses the understanding of alternative sources of income adapted by local communities to survive during COVID-19 and their implications for biodiversity conservation. This study is important because it provides basic data on the magnitude of the COVID-19 pandemic's socioeconomic repercussions while emphasizing the numerous alternative sources of revenue used by community members adjacent to the Burunge WMA during the crisis. The results of this research will assist responsible authorities and communities in adopting effective approaches and strategies to prevent the effects of unexpected tragedies such as COVID-19, as well as modify some policies for the interest of protected areas and nearby local communities.

\section{Materials And Methods \\ 2.1. Study area}

This study was conducted across three selected villages that were purposefully selected, namely, Kakoi, Maweni, and Mwada found in the Burunge Wildlife Management Area (WMA) within the TarangireManyara Ecosystem (TME). The villages that were included in this study benefited from the Burunge WMA directly or indirectly. The Burunge WMA has a size of $617 \mathrm{~km}^{2}$, of which $280 \mathrm{~km}^{2}$, is reserved for conservation activities. The Burunge WMA is found in the Tarangire-Manyara Ecosystem (TME) between latitude $3.94^{\circ} \mathrm{S}$ to $3.66^{\circ} \mathrm{S}$ and longitude $35.73^{\circ} \mathrm{E}$ to $35.97^{\circ} \mathrm{E}$ in the Babati district in the Manyara region (figure 1) (Kiffner et al., 2020; WWF, 2014). This area records a temperature of approximately $180^{\circ} \mathrm{C}$ to $330^{\circ} \mathrm{C}$ with alternating seasons (dry, long, and short) of 400 to $500 \mathrm{~mm}$ rainfall annually at an elevation of $1,000 \mathrm{~m}$ from the sea level. The types of plants that dominated the area include edaphic grasslands, riverine vegetation, and Acacia woodlands. There are mainly two ethnic groups that are dominant around the Burunge WMA: Mbugwe which are agro-pastoralists and Maasai, which are pastoralists (Kaswamila, 2012).

Wildlife Management Area (WMA) in the Tarangire-Manyara Ecosystem (TME)

Note

PAs - Protected Areas

\subsection{Individuals (households) recruited for data collection}


The sample population used in this study was selected from three villages around Burunge WMA. A total sample size of 264 respondents was selected from three villages (Kakoi $=79$, Maweni $=68$, and Mwada $=$ 117). The sample size used was at least $5 \%$ of the entire population projected for this study, as suggested by NIST (2020). Under the consent and guidance of local government authorities, the number of respondents from each study area was determined by considering the population size of the village. The respondents were selected from each study village, and a list of villagers was provided by local government leaders in each village. Each member in a list was numbered, and random selection was performed using the random function from the excel sheet "= RAND ()" to obtain the individual (household) to be recruited for the interview. Semi-structured questionnaires were used to collect data from the selected respondents. Respondents were those aged 18 years and above, with the assumption that in this age category, a respondent will be involved in a particular socioeconomic activity to earn income. Furthermore, focus group discussions (FGDs) were held intensively with a group of at least four respondents to obtain more information on the specific issue. The questions asked in the focused group discussion were those provided in the questionnaire, although flexibility was allowed to ensure that more information was captured from the respondents. In addition, comprehensive information on this study was gathered from key informants. The recruited key informants included 3 Burunge WMA leaders, 2 local government leaders, 3 conservationists in the Tarangire Manyara Ecosystem and 2 rangers. The information gathered from the respondents, focus group discussions (FGDs), and key informants were about socio-economic status during the COVID-19 pandemic, alternative sources of income during the COVID-19 pandemic, the status of the tourism sector and conservation during COVID-19, and any report regarding the impact of COVID-19 on biodiversity (mostly for key informants). In addition, an extensive and systematic literature review was conducted to explore the anticipated impact of COVID-19 on biodiversity conservation, income from the tourism sector, in agreement with the objectives of this study.

\subsection{Socio-economic status during the COVID-19 pandemic}

For each respondent, a semi-structured questionnaire was provided to collect data on the socio-economic activities they engaged in. Friendly socio-economic activities are significant in the conservation of biodiversity and any negative shift of local communities to other activities as a result of the COVID-19 pandemic is anticipated to cause problems in these areas. The socio-economic activities practiced by the respondents were collected from each village. In the questionnaire, the effects of COVID-19 on the socioeconomic practices of the respondents were inquired from each respondent. To increase the scope of the explored issue, intensive focus group discussions (FGDs) were held with each group having not less than four respondents.

\subsection{Alternative sources of income during the COVID-19 pandemic}

From the semi-structured questionnaires provided to the respondents, focus group discussions (FGDs) and key informants, information on the alternative sources of income adapted by the local communities as a means of survival during the COVID-19 pandemic was acquired. The alternative sources of income were those activities that the local communities decided to go and practice; specifically those whose 
former sources of income were disrupted by COVID-19. The alternative sources of income considered here were: agriculture, fishing, livestock keeping, Boda-Boda (motorcycle taxis), restaurants, and other small-to-medium enterprises.

\subsection{The status of tourism sector and conservation during COVID-19}

More information was sought from respondents and key informants to better understand the status of COVID-19 in the WMA management area. Respondents were asked if the number of tourists in the study area was increasing, decreasing, or stable, particularly during the COVID-19 crisis. The classification for rating the number of tourists observed was very low (1-9 tourists observed per week), low (10-29 tourists observed per week), high (30-49 tourists observed per week), and very high (50 and above tourists observed per week). The respondents were asked to rate the number of tourists observed during COVID-19 and pre-COVID-19. In this case, the time for COVID-19 was March-May 2020, when the disease was declared and many countries practiced the so-called lockdown, while pre-COVID-19 was March-May 2019, when people were free and there was no declared COVID-19 and lockdown.

\subsection{Implication and impact of COVID-19 on biodiversity conservation (Ecological impact)}

An extensive review of both online and printed information was systematically done (Khan et al., 2003; McDonagh et al., 2000). During the search for the required documents, language was not a barrier or restriction. Some of the key words, as shown in Table 1 below, were used to enable the acquaintance of relevant literature for this study on both the internet and printed documents. To obtain the targeted studies for review, search engines including Google scholar (https://scholar.google.com/), BASE (https://www.base-search.net/) and Research Gate (https://www.researchgate.net) were employed, while a manual search was conducted to search the information from printed documents, including proceedings, official government reports, posters and other publications that were not available on the internet during the review. The explored and required information in the reviewed literature was about biodiversity conservation, human biodiversity interaction and the anticipated ecological impact of COVID19 on the conservation of biological diversity.

Table 1: Identification, screening and eligibility of the documents included during literature review 


\begin{tabular}{|c|c|c|c|}
\hline $\begin{array}{l}\text { Identification } \\
\text { (Record from } \\
\text { :) }\end{array}$ & Screening & Eligibility & $\begin{array}{l}\text { Keywords } \\
\text { used for } \\
\text { searching }\end{array}$ \\
\hline $\begin{array}{l}\text { Google } \\
\text { scholar } \\
(n=45) \\
\text { Research } \\
\text { gate }(n=24) \\
\text { Bielefeld } \\
\text { Academic } \\
\text { Search } \\
\text { Engine } \\
(n=11) \\
\text { Manual } \\
\text { search }(n=5)\end{array}$ & $\begin{array}{l}\text { Screened } \\
\text { documents } \\
(\mathrm{n}=85) \\
\\
53 \text { Included - } \\
\text { full texts } \\
32 \text { Excluded - } \\
\text { had only } \\
\text { titles/abstracts } \\
\text { related to the } \\
\text { subject }\end{array}$ & $\begin{array}{l}39 \text { full texts included, } 14 \text { excluded }- \text { had no } \\
\text { required ecological information, detailed } \\
\text { conservation issues, socio-economic status of } \\
\text { local communities in relation to the outbreak of } \\
\text { COVID-19 pandemic }\end{array}$ & $\begin{array}{l}\text { COVID-19, } \\
\text { Protected } \\
\text { Areas } \\
\text { Wildlife } \\
\text { Management } \\
\text { Areas } \\
\text { (WMAs), } \\
\text { Local } \\
\text { communities } \\
\text { adjacent } \\
\text { protected } \\
\text { areas, } \\
\text { Alternative } \\
\text { sources of } \\
\text { income }\end{array}$ \\
\hline
\end{tabular}

\subsection{Income status during the years (2019-2021) of COVID- 19 outbreak in Burunge WMA}

The data on income generated by Burunge WMA were collected from secondary data, specifically the report kept by the WMA management from 2006 to 2021. The data included the total revenue collected each year. The purpose of collecting this information was to understand the trend of revue collection and point out the effect of COVID-19 on revenue or income collection by WMA management. The time of COVID-19 in this trend was 2019/2020 and 2020/2021. The sources of income include fines, hunting and photographic tourism, with the tourism sector contributing $99 \%$ of the total collected revenue.

\subsection{Data analysis}

Microsoft Excel ${ }^{\circledR}$ (Microsoft Corporation, Washington, USA) was used to record, classify, and organize the collected data. The analysis was performed using SYSTAT (Version 13.2 Inc. 2017) (http://www.systat.com) at a significance level of 0.05. A non-parametric statistical test (Kruskal-Wallis statistical test or Mann-Whitney $\mathrm{U}$ test) was used to test the variation of variables such as, the information obtained on the socio-economic activities of the respondents, the number of tourists before and during COVID-19 on tourists, and the alternative sources of income adapted by the local communities adjacent to the Burunge WMA during the COVID-19 pandemic as a means of survival. Other descriptive statistics including, percentage and cross-tabulation were also used. In addition, graphs, tables, and charts were included to present a large amount of data in a detailed and simple manner.

\section{Results}

\subsection{Socio-demographic profile of respondents}


A total of 264 respondents from the three study areas were considered for participation in the study, of which 79, 68, and 117 respondents were selected from Kakoi, Maweni, and Mwada villages, respectively. There were 140 male respondents (53\%), and 124 female respondents (47\%) in the survey. Kakoi village had a large percentage of male participants with $62 \%(n=49)$ as compared to other villages whereas the number of female participants was higher in Maweni village with $51.5 \%(n=35)$. The variation observed in gender distribution among the three study villages was not significant (Kruskal-Wallis Test Statistic = $3.872, P=0.144)$. In the case of age groups, the youth group dominated the population with $79.9 \%$ $(n=211)$ followed by the adult group $17.8 \%(n=47)$. Maweni village had a large percentage of youths with $91.2 \%(n=62)$ and Kakoi was the least with $64.6 \%(n=51)$. The percentage of the old group across the three study villages was the smallest with a total of $2.3 \%(n=6)$. The variation in age groups across the three study villages was significant (Kruskal-Wallis Test Statistic $=17.118, \mathrm{P}<0.01$ ). In addition to the collected information, the education level of respondents was also recorded, whereby a large number of respondents had primary education $(44.7 \%, n=118)$, followed by secondary education $(40.2 \%, n=106)$, tertiary education $(10.2 \%, n=27)$, and $4.9 \%(n=13)$ for informal education. The Kruskal-Wallis test showed that the distribution of education levels across the study villages was not significant (KruskalWallis Test Statistic $=5.967, \mathrm{P}=0.051)($ Table 2) .

Table 2: Socio-demographic characteristics of the respondents in the three study areas (Kakoi,

Maweni and Mwada)

\begin{tabular}{|c|c|c|c|c|c|c|c|}
\hline $\mathrm{S} / \mathrm{n}$ & Variable & Categories & $\begin{array}{l}\text { Kakoi \% } \\
(n=79)\end{array}$ & $\begin{array}{l}\text { Maweni \% } \\
(\mathrm{n}=68)\end{array}$ & $\begin{array}{l}\text { Mwada \% } \\
(n=117)\end{array}$ & $\begin{array}{l}\text { Test } \\
\text { statistic }\end{array}$ & $P$ \\
\hline \multirow[t]{2}{*}{1} & \multirow[t]{2}{*}{ Gender } & Female & $38(30)$ & $48.5(33)$ & $52.1(61)$ & \multirow[b]{2}{*}{3.872} & \multirow[t]{2}{*}{0.144} \\
\hline & & Male & $62(49)$ & $51.5(35)$ & $47.9(56)$ & & \\
\hline \multirow[t]{3}{*}{2} & \multirow[t]{3}{*}{ Age } & $\begin{array}{l}18-40 \\
\text { (Youth) }\end{array}$ & $64.6(51)$ & $91.2(62)$ & 83.8(98) & \multirow{3}{*}{17.118} & \multirow[t]{3}{*}{$\begin{array}{l}<.01 \\
0.01\end{array}$} \\
\hline & & $\begin{array}{l}41-60 \\
\text { (Adult) }\end{array}$ & $32.9(26)$ & $5.9(4)$ & $14.5(17)$ & & \\
\hline & & $>60$ (Old) & $2.5(2)$ & $2.9(2)$ & $1.7(2)$ & & \\
\hline \multirow[t]{4}{*}{3} & \multirow{4}{*}{$\begin{array}{l}\text { Education } \\
\text { level }\end{array}$} & Informal & $5.1(4)$ & $5.9(4)$ & $4.3(5)$ & \multirow{4}{*}{5.967} & \multirow[t]{4}{*}{0.051} \\
\hline & & Primary & $57(45)$ & $35.3(24)$ & $41.9(49)$ & & \\
\hline & & Secondary & $30.4(24)$ & $57.4(39)$ & $36.8(43)$ & & \\
\hline & & Tertiary & $7.6(6)$ & $1.5(1)$ & $17.1(20)$ & & \\
\hline
\end{tabular}

The respondents were involved in several socio-economic activities including fishing $4.2 \%(n=11)$, agriculture $28 \%(n=74)$, livestock keeping $17.8 \%(n=47)$, handcrafting activities $10.6 \%(n=28)$, small-to- 
medium enterprises (SME) 22.3\% ( $n=59)$, and hunting $0.4 \%(n=1)$ while others were employed in various sectors including the industrial and education sector $16.7 \%(n=44)$. The difference across the three villages on the dominant socio-economic activities was noticed whereby; at Kakoi village, the dominant socio-economic activity was agriculture $25.3 \%(n=20)$, followed by livestock keeping $22.8 \%(n=18)$, smallto-medium enterprises (SME) 21.5\% ( $n=17)$, employed 12.7\% ( $n=10)$, fishing 6.3\% $(n=5)$, and handcrafting activities $11.4 \%(n=9)$ whereas $19.1 \%(n=13), 1.5 \%(n=1), 13.2 \%(n=9), 25 \%(n=17), 26.5 \%(n=18), 13.2$ $(n=9)$, and $1.5 \%(n=1)$ were for agriculture, fishing, handcrafting activities, livestock keeping, small-tomedium enterprises (SME), employed and hunting respectively in Maweni village while Mwada village had 35\% $(n=41)$ for agriculture, 4.3\% $(n=5)$ for fishing, 8.5\% $(n=10)$ for handcrafting activities, $10.3 \%$ $(n=12)$ for livestock keeping, 20.5\% ( $n=24)$ for small-to-medium enterprises (SME) and $21.4 \%(n=25)$ for employed. The variation observed in socio-economic activities across the three study villages was significant (Kruskal-Wallis Test Statistic $=8.765, \mathrm{P}=0.012)($ figure 2$)$.

Mwada)

Note

SME - Small-to-medium enterprises

\subsection{Socio-economic activities versus COVID-19 pandemic}

The impact of the COVID-19 pandemic was experienced by a large number of respondents in the three study sites, with $90.5 \%(n=239)$ of all respondents agreeing that COVID-19 had an impact on their livelihoods, while only $9.5 \%(n=25)$ claimed COVID-19 had no impact on their livelihoods. The impacts caused by the COVID-19 pandemic were mainly; deflation which leads to low income $91.7 \%(n=242)$, losing jobs $5.7 \%(n=15)$, and decline in the number of customers $91.7 \%(n=242)$, each one was calculated out of the total number of respondents. The percentage of respondents who lost their jobs due to COVID19 was higher in Mwada village with 7.7\% ( $n=9)$ than in other villages. Of the respondents, $97.2 \%(n=66)$ reported a decline in income, Maweni village had the highest proportion, while Mwada village had the lowest, with $87.2 \%(n=102)$, with no significant variation across the three study villages (Kruskal-Wallis Test Statistic $=3.182, \mathrm{P}=0.204)($ Table 3$)$.

Table 3: Impact of COVID-19 on socio-economic activities across the three study villages (Kakoi, Maweni and Mwada) 


\begin{tabular}{|c|c|c|c|c|c|c|}
\hline Variable & Response & $\begin{array}{l}\text { Kakoi \% } \\
(n=79)\end{array}$ & $\begin{array}{l}\text { Maweni \% } \\
(n=68)\end{array}$ & $\begin{array}{l}\text { Mwada \% } \\
(n=117)\end{array}$ & $\begin{array}{l}\text { Test } \\
\text { statistic }\end{array}$ & $\mathbf{P}$ \\
\hline \multirow{2}{*}{$\begin{array}{l}\text { Decline in number of } \\
\text { customers }\end{array}$} & NO & $6.3(5)$ & $2.9(2)$ & $12.8(15)$ & \multirow[t]{2}{*}{6.065} & \multirow[t]{2}{*}{$0.04 \varepsilon$} \\
\hline & YES & $93.7(74)$ & $97.1(66)$ & $87.2(102)$ & & \\
\hline \multirow[t]{2}{*}{ Decline in income } & NO & $6.3(5)$ & $2.9(2)$ & $12.8(15)$ & \multirow[t]{2}{*}{6.065} & \multirow[t]{2}{*}{0.048} \\
\hline & YES & $93.7(74)$ & $97.1(66)$ & $87.2(102)$ & & \\
\hline \multirow[t]{2}{*}{ Losing jobs } & NO & $93.7(74)$ & $98.5(67)$ & $92.3(108)$ & \multirow[t]{2}{*}{3.182} & \multirow[t]{2}{*}{0.204} \\
\hline & YES & $6.3(5)$ & $1.5(1)$ & 7.7(9) & & \\
\hline
\end{tabular}

\subsection{Alternative sources of income during the COVID-19 pandemic}

The alternative sources of income adapted by the local communities adjacent to the Burunge WMA during the COVID-19 pandemic include fishing 9.5\% ( $n=25)$, shops selling 5.7\% ( $n=15)$, Boda-Boda (Motorcycle taxis) $3.4 \%(n=9)$, agriculture 22.3\% ( $n=59)$, livestock keeping $27.3 \%(n=72)$, vendors $0.4 \%$ $(n=1)$ and restaurants $2.3 \%(n=6)$ whereas $22.3 \%(n=59)$ had no alternative sources of income. Different people adapted different alternative sources of income in their respective areas, for instance; In Kakoi village; the dominant alternative sources of revenue were agriculture $20.3 \%(n=16)$ and livestock keeping $20.3 \%(n=16)$ whereas agriculture 29.9\% $(n=35)$ and livestock keeping 39.7\% ( $n=27)$ were the dominant socioeconomic activities for Mwada and Maweni respectively. Mwada village has experienced a large percentage of individuals with no alternative sources of income with $24.8 \%(n=29)$ as compared to other villages. The variation in alternative sources of income during the COVID-19 pandemic across the three study villages was significant (Kruskal-Wallis Test Statistic $=7.898, P=0.019)($ Table 4).

Table 4: The alternative sources of income adapted by respondents during COVID-19 across the Three study villages (Kakoi, Maweni and Mwada) 


\begin{tabular}{|c|c|c|c|c|c|}
\hline Variable & $\begin{array}{l}\text { Kakoi \% } \\
(n=79)\end{array}$ & $\begin{array}{l}\text { Maweni \% } \\
(n=68)\end{array}$ & $\begin{array}{l}\text { Mwada \% } \\
(n=117)\end{array}$ & $\begin{array}{l}\text { Test } \\
\text { statistic }\end{array}$ & $P$ \\
\hline Fishing & 17.7(14) & $8.8(6)$ & $4.3(5)$ & \multirow[t]{9}{*}{7.898} & \multirow[t]{9}{*}{0.01} \\
\hline Agriculture & $20.3(16)$ & $11.8(8)$ & $29.9(35)$ & & \\
\hline $\begin{array}{l}\text { Boda-Boda (Motorcycle } \\
\text { taxis) }\end{array}$ & 0 & $1.5(1)$ & $6.8(8)$ & & \\
\hline Livestock keeping & $20.3(16)$ & $39.7(27)$ & $24.8(29)$ & & \\
\hline Handcrafting & $11.4(9)$ & $4.4(3)$ & $5.1(6)$ & & \\
\hline Shop selling & $5.1(4)$ & $10.3(7)$ & $3.4(4)$ & & \\
\hline Restaurants & $1.3(1)$ & $5.9(4)$ & $0.9(1)$ & & \\
\hline Vendors & 0 & $1.5(1)$ & 0 & & \\
\hline No alternative & 24.1(19) & $16.2(11)$ & $24.8(29)$ & & \\
\hline
\end{tabular}

\subsection{The status of tourism sector and conservation during COVID-19}

The number of tourists flowing in the country particularly in the Burunge WMA declined sharply during the COVID-19 pandemic compared to a few years back. According to their observations, $96.2 \%(n=254)$ respondents argued that the number of tourists before COVID-19 was high, whereas $3 \%(n=8)$ and $0.8 \%$ $(n=2)$ were for those who said the number of tourists was very high and others didn't know respectively with the variation being not significant across the three study areas (Kruskal-Wallis Test Statistic $=0.156$, $P=0.925)$. In the same regard, $94.3 \%(n=249)$ of respondents agreed that the number of tourists observed during the COVID-19 pandemic crisis was low compared to some months back, while $4.5 \%$ $(n=12)$ were for the respondents who said the number of tourists was very low and $1.1 \%(n=3)$ for those who didn't know. The variation in responses across the three study villages was not significant (KruskalWallis Test Statistic $=0.089, \mathrm{P}=0.956)($ Table 5).

Table 5: The responses from respondents from three study villages (Kakoi, Maweni, and Mwada) in the variation of the number of tourists as observed in their areas near Burunge WMA 


\begin{tabular}{|c|c|c|c|c|c|c|}
\hline Variable & Response & $\begin{array}{l}\text { Kakoi \% } \\
(n=79)\end{array}$ & $\begin{array}{l}\text { Maweni \% } \\
(n=68)\end{array}$ & $\begin{array}{l}\text { Mwada \% } \\
(n=117)\end{array}$ & $\begin{array}{l}\text { Test } \\
\text { statistic }\end{array}$ & $P$ \\
\hline \multirow{5}{*}{$\begin{array}{l}\text { Number of tourists } \\
\text { before COVID-19 }\end{array}$} & Very high & $1.3(1)$ & $4.4(3)$ & $3.4(4)$ & 0.156 & 0.925 \\
\hline & High & $97.5(77)$ & $95.6(65)$ & $95.7(112)$ & & \\
\hline & Low & 0 & 0 & 0 & & \\
\hline & Very low & 0 & 0 & 0 & & \\
\hline & $\begin{array}{l}\text { Don't } \\
\text { know }\end{array}$ & $1.3(1)$ & 0 & $0.9(1)$ & & \\
\hline \multirow{5}{*}{$\begin{array}{l}\text { Number of tourists } \\
\text { during COVID-19 }\end{array}$} & Very high & 0 & 0 & 0 & 0.089 & 0.956 \\
\hline & High & 0 & 0 & 0 & & \\
\hline & Low & $94.9(75)$ & $94.1(64)$ & $94(110)$ & & \\
\hline & Very low & $2.5(2)$ & $5.9(4)$ & $5.1(6)$ & & \\
\hline & $\begin{array}{l}\text { Don't } \\
\text { know }\end{array}$ & $2.5(2)$ & 0 & $0.9(1)$ & & \\
\hline
\end{tabular}

\subsection{Income status during the years (2019-2021) of COVID- 19 outbreak in Burunge WMA}

From $2006 / 2007$ to $2020 / 2021$, the total amount of TZS $10,773,236,671.06$ was collected by the Burunge WMA. Of this, the least amount of income of about TZS 37,496,988.00 was collected in 2006/2007, while the highest amount of TZS 2,071,861,968.00 was collected in 2017/2018. There was a significant increase in revenue throughout until 2012/2013 when a drop of up to TZS 275,428,061.96 from TZS $473,738,859.93$ was recorded. After that, the situation recovered until the years 2019/2020 and 2020/2021 during COVID-19, where revenue collected declined to TZS 476,740,689.00 from the maximum collected amount of about TZS 2,018,880,629.67 in 2018/2019 before COVID-19 (Figure 3). The rate of revenue decline due to COVID 19 from 2019/2020 to $2020 / 2021$ was $32.5 \%$ and $76.4 \%$, respectively, as compared to the year 2018/2019.

during COVID-19 pandemic (2019-2021)

\subsection{The anticipated impact of COVID-19 on biodiversity conservation (Ecological impact)}

The evidence from the reviewed literature shows that the effects of the COVID-19 pandemic on biological diversity conservation can be directly or indirectly caused by several factors and seen in different ways and perspectives (Figure 4). Some of the effects caused by the COVID-19 pandemic include habitat destruction and conversion, an increase in human-wildlife conflict, and the transmission of zoonotic diseases due to an increase in human, wildlife, and livestock interaction (Table 6). 
Table 6: The anticipated negative influence of COVID-19 on the biodiversity conservation within and around the Burunge WMA 


\begin{tabular}{|c|c|c|c|}
\hline $\begin{array}{l}\text { Driver of changes (During } \\
\text { COVID-19) }\end{array}$ & $\begin{array}{l}\text { Outcomes } \\
\text { (Actions) }\end{array}$ & $\begin{array}{l}\text { Impact on } \\
\text { biodiversity } \\
\text { conservation } \\
\text { (Ecological } \\
\text { impact) }\end{array}$ & References \\
\hline \multirow[t]{10}{*}{$\begin{array}{l}\text { Major alternative sources of } \\
\text { income as adapted by local } \\
\text { communities adjacent the } \\
\text { Burunge WMA }\end{array}$} & \multirow[t]{4}{*}{$\begin{array}{l}\text { - Intensive } \\
\text { agriculture within } \\
\text { and around the } \\
\text { PAs }\end{array}$} & $\begin{array}{l}\text { - Habitat } \\
\text { conversion, } \\
\text { loss \& } \\
\text { degradation }\end{array}$ & \multirow[t]{4}{*}{$\begin{array}{l}\text { (Mmbaga et al., 2017; Seki et } \\
\text { al., 2018; Sigala et al., 2021; } \\
\text { Spenceley et al., 2021; } \\
\text { Walters et al., 2021) }\end{array}$} \\
\hline & & $\begin{array}{l}\text { - Unfavorable } \\
\text { LULCC within } \\
\text { and around the } \\
\text { PAs }\end{array}$ & \\
\hline & & $\begin{array}{l}\text { - Accelerate } \\
\text { human-wildlife } \\
\text { conflicts }\end{array}$ & \\
\hline & & $\begin{array}{l}\text { - Land } \\
\text { isolation and } \\
\text { patches }\end{array}$ & \\
\hline & \multirow[t]{3}{*}{$\begin{array}{l}\text { - Increased } \\
\text { livestock keeping } \\
\text { (large herds of } \\
\text { livestocks) }\end{array}$} & $\begin{array}{l}\text { - Habitat } \\
\text { conversion, } \\
\text { loss \& } \\
\text { degradation }\end{array}$ & \multirow[t]{3}{*}{$\begin{array}{l}\text { (Ngongolo, 2020; Seki et al., } \\
\text { 2018; Sigala et al., 2021) }\end{array}$} \\
\hline & & $\begin{array}{l}- \\
\text { Transmission } \\
\text { of zoonotic } \\
\text { diseases }\end{array}$ & \\
\hline & & $\begin{array}{l}\text { - Soil erosion } \\
\text { \& degradation }\end{array}$ & \\
\hline & \multirow{3}{*}{$\begin{array}{l}\text { - Intensive fishing } \\
\text { activities (Illegal } \\
\text { fishing methods } \\
\text { e.g. poisoning) }\end{array}$} & - Over-fishing & \multirow{3}{*}{$\begin{array}{l}\text { (Seki et al., 2018; Waithaka et } \\
\text { al., 2021; Walters et al., 2021) }\end{array}$} \\
\hline & & $\begin{array}{l}\text { - Disruption of } \\
\text { ecological } \\
\text { processes in } \\
\text { water } \\
\text { ecosystem }\end{array}$ & \\
\hline & & $\begin{array}{l}\text { - Eruption of } \\
\text { food chain in } \\
\text { the water } \\
\text { habitats }\end{array}$ & \\
\hline
\end{tabular}




\begin{tabular}{|c|c|c|c|}
\hline $\begin{array}{l}\text { Driver of changes (During } \\
\text { COVID-19) }\end{array}$ & $\begin{array}{l}\text { Outcomes } \\
\text { (Actions) }\end{array}$ & $\begin{array}{l}\text { Impact on } \\
\text { biodiversity } \\
\text { conservation } \\
\text { (Ecological } \\
\text { impact) }\end{array}$ & References \\
\hline $\begin{array}{l}\text { Collapse of several local } \\
\text { businesses (e.g. } \\
\text { handcrafting activities) }\end{array}$ & $\begin{array}{l}\text { - Decline in } \\
\text { number of } \\
\text { customers } \\
\text { - Reduced sales } \\
\text { - Job loss }\end{array}$ & $\begin{array}{l}\text { - Increased } \\
\text { poaching } \\
\text { activities } \\
\text { - Illegal tree } \\
\text { cutting } \\
\text { (deforestation } \\
\& \text { timber } \\
\text { logging) } \\
\text { - } \\
\text { Encroachment } \\
\text { in protected } \\
\text { area (Burunge } \\
\text { WMA) }\end{array}$ & $\begin{array}{l}\text { (Kideghesho et al., 2021; } \\
\text { Shoo et al., 2021; Walters et } \\
\text { al., 2021) }\end{array}$ \\
\hline
\end{tabular}

Minimal visitation of tourists in the Burunge WMA

\begin{abstract}
- Loss
of
\end{abstract} revenues
- Instability of community based conservation

- Failure to implement different development projects in the participating villages

- Tour guides lost their jobs

- Provision of environmental education to the local communities stopped

- Reduced numbers of patrols
(Kideghesho et al., 2021; Shoo et al., 2021; Spenceley et al., 2021; Walters et al., 2021)
(Kideghesho et al., 2021; Shoo et al., 2021; Walters et al., 2021)

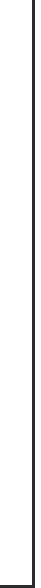


group as compared to the other groups. It was observed that, a large number of individuals in this age group were more involved in different socioeconomic activities than the others. At the age of 18-40 years, a person becomes energetic and capable of performing several duties efficiently under minimal supervision. This age group has been referred to as more active and productive in society because of its contribution of doing various activities for the welfare of their own families as well as the local communities (URT, 2006). According to Morar \& Peterlicean (2012), the complexity of environmental problems can be mitigated by re-channeling education to the youth group on the importance and usefulness of nature to stimulate sustainable development in both conservation issues and local communities' livelihoods. In addition, Nadeson \& Barton (2014) argued that youth are innovative, continually growing, problem solving oriented, passionate and knowledgeable; thus, investing in them would bring about a huge positive impact on conservation of biodiversity and improvement of livelihoods in societies. The majority of respondents had a primary education level followed by a secondary education level as it is in most families of farmers and pastoralists in many African countries and Tanzania in particular. The findings in this study suggest the need and importance of educating and empowering youth groups for the benefit of society as well as the conservation of wildlife and natural resources as they are the main custodians of the protected areas in agreement with other studies (Morar \& Peterlicean, 2012; Nadeson \& Barton, 2014).

\subsection{Socio-economic characteristics of the respondents}

The findings from the study revealed that the majority of the surveyed residents adjacent to the Burunge WMA were undertaking different types of activities, however, farming, fishing, and cattle keeping were the predominant means of generating profit. The socio-economic activities varied slightly from one village to another. For example, most of the individuals in Mwada village were farmers, while those in Kakoi and Maweni were engaged in livestock husbandry and farming practices. The variation in socio-economic activities encountered between the three areas of study was possibly influenced by multiple factors, such as the proportion of a certain age category over the other, the availability and accessibility of land for agricultural purposes, and pastures as well as the proximity of a specific area to the protected area. This is in agreement with earlier studies conducted in villages surrounding protected and conserved areas in many places particularly Tanzania. For instance, a study by Kaswamila (2009) in the Esilalei, Barabarani, and Migombani villages within the Tarangire-Manyara ecosystem indicated that the primary socioeconomic activities in these locations are subsistence farming, cattle husbandry, and other tourism-based activities. Moreover, research conducted in villages near Saadani National Park (SANAPA) indicated that many indigenous and local societies situated near protected and conserved areas depend largely on agricultural practices and livestock keeping, and that the observed variation among such villages was influenced by the size of the local people's landholdings and the geographical location of the specific villages to the parklands (Komba et al., 2021; Mmbaga et al., 2021; Moshi, 2016).

\subsection{Socio-economic activities versus COVID-19 pandemic}

The three research areas faced the misery of the COVID-19 pandemic in their socio-economic activities. The study reveals that the local communities located adjacent to the protected areas encountered several 
issues, including a decrease in the number of customers and deflation, leading to reduced income in nearly the same range throughout the three study villages. It was further noticed that in Mwada village, the percentage of individuals who had lost their jobs due to the COVID-19 pandemic was greater in comparison to the other surveyed places. The reason underlying this was the dependence of local communities on the tourism industry and other WMA-linked activities. Similar results have been reported in other countries and worldwide. For example, research performed in five selected WMAs indicated that nearly all the tour operators at Ikona WMA lost their jobs as a result of the COVID-19 pandemic, whereas the same has been noticed in Enduimet, Randiren, Burunge, and Makao WMA where some workers, particularly those paid by the local communities, were given leave without receiving their wages, while others were working on loans (Shoo et al., 2021). Further results in Malawi have shown that a huge number of local communities involved with agriculture, bee-keeping, and fishing suffered significantly as a result of the COVID-19 outbreak. The decline in the number of visitors in protected areas in Malawi due to the COVID-19 pandemic, who were the main buyers of honey and other commodities, resulted in a downturn in sales in the market, thus significantly affecting their lives (Attah, 2021). Furthermore, research performed by Kideghesho et al (2021), noticed that the majority of people operating in the informal economy around protected zones had reduced demand, sales, and market for their commodities.

\subsection{Alternative sources of income during the COVID-19 pandemic}

As a mechanism for survival during the COVID-19 juncture, community members had to discover new means of earning income for their livelihoods. In Kakoi, Maweni, and Mwada villages, people shifted to other alternative approaches for their lives, including farming, livestock husbandry, and fishing while others engaged in Boda-Boda (Motorcycle taxis), restaurants, and other enterprises. Others had no alternative sources of earning income; the scenario described by FAO (2020) caused people to break several regulations and rules to sustain their livelihoods. The study found that the abovementioned activities captured the attention of many because they were the only available ways of generating profits for the indigenous and local people besides the protected areas during the COVID-19 pandemic. In addition, the aforementioned activities were among the most familiar socio-economic tasks performed by many local communities, and thus most had prior experience on how to operate and run them accordingly. The findings revealed that the repercussions caused by COVID-19 on income and sales in markets led to the minimal collection of personal revenues; hence, they were not capable of providing all basic requirements for their families. Uncontrolled livestock keeping and intensive farming among other activities have been termed by several studies to be more dangerous for the existence of natural habitats and wildlife species (Seki et al., 2018). The massive flow of people from different places into the local villages as a means to ensure their safety during the COVID-19 pandemic is likely to increase pressure on land use and natural resource exploitation, thereby threatening natural habitats and wildlife growth. For instance, it was observed that a large number of people moved from urban areas to rural areas especially those working in the informal economy to search for alternative means of livelihood (Kideghesho et al., 2021). The urban-rural movement of the people tends to increase the population size while the resources are limited; as a result, other residents may engage in illegal activities including poaching and 
deforestation to earn their living (Kideghesho et al., 2021). As supported by Loibooki et al. (2002) and Knapp (2012), the close linkage between the diversification of sources of earning income and illegal conduct inside or around protected and conserved areas may induce unfavorable land use/ land change cover thus leading to the destruction of wildlife species and natural habitats.

\subsection{The status of tourism sector and conservation during COVID-19}

The findings in this study show that, the number of tourists visiting Tanzania declined massively as identified by the respondents with little variation between their responses. It was noticed that the number of tourists registered within a week fell from about 300 visitors before the COVID-19 outbreak to at most 9 visitors during this pandemic. These findings are in agreement with the results obtained by UNWTO (2020a, 2020b), which puts an estimate of about 20-30\% fall of tourist arrivals worldwide in the year 2020 compared to 2019 as a result of the COVID-19 pandemic. In addition, the findings of the survey conducted by Safaribookings.com (2021) revealed a sharp decrease in booking requests from potential customers from different countries across the globe. For instance, there was a decline of more than $75 \%$ (> 75\%) (184 operators/ $68.7 \%$ of all operators) requests in new booking as a result of the COVID-19 outbreak whereas there was an increase of more than $75 \%$ (> 75\%) in cancellation of existing bookings (134 operators/ $50.0 \%$ of all operators) (Safaribookings.com, 2021). The $90 \%$ dependence of many WMAs in Tanzania on tourism activities, mainly photographic and hunting tourism (Shoo et al., 2021), deteriorated the conservation issues and other operations of these protected areas in a very destructive way. As such, there is a need to have diversified means of collecting revenue rather than relying entirely on tourism.

\subsection{Income status during the years (2019-2021) of COVID- 19 outbreak in Burunge WMA}

It was clear from the findings that the revenue decline halted potential operations in the Burunge WMA. The reported fall in collected income forced the management to minimize necessary expenditures and focus much more on very sensitive operations such as combating poaching through patrols, although the challenges were still there. For instance, the budget for oil/diesel for patrolling inside and around the WMA was reduced from $3,000,000$ (USD 1,302.93) to TZS 1,000,000 (USD 434.31). Burunge WMA depends greatly on mainly photographic and hunting tourism for its revenue. Therefore, the massive decline in the number of tourists due to COVID-19 dragged them into a messy ending. These findings correspond with those reported by UNWTO $(2020 a, 2020$ c $)$, where a loss of approximately USD 300-450 billion was estimated due to the decline in the number of tourist arrivals worldwide and so does in Tanzania. Moreover the study conducted by Spenceley et al (2021) and Hockings et al (2020) shows that the same situation and fall-down was also experienced by other countries including Indonesia, United States of America and Canada.

\subsection{The anticipated impact of COVID-19 on biodiversity conservation (Ecological impact)}

Page $18 / 28$ 
Apart from having a direct impact on the protected and conserved areas, including WMAs, the COVID-19 pandemic has also indirectly influenced the likelihood of threatening the survival of several species, the existence and sustainability of their natural habitats. The disturbance and disruption of various socioeconomic activities, especially tourist-dependent local businesses including handcrafting activities, conducted by the local communities adjacent to the protected area (i.e., Burunge WMA), has caused some negative repercussions. A large number of indigenous and local people turned to other activities, including intensive agriculture and livestock keeping, which once conducted inappropriately, become dangerous for the survival of wildlife and their natural habitats (Seki et al., 2018; Spenceley et al., 2021; Walters et al., 2021). Moreover, as highlighted in this study's findings, the sharp and intense decline in the number of tourists in many protected areas worldwide, and Tanzania in particular, exacerbated the difficulties in management and achievement of planned and targeted goals in many ways. The massive loss of revenue as a result of the COVID-19 pandemic led to the failure of several managerial issues and developmental projects not just within the protected area but also in the participating local communities, in agreement with other studies, including those conducted by Kideghesho et al (2021) and Shoo et al (2021). The COVID-19 pandemic has been reported to have nothing to do with the issue of poaching and other illegal activities in the Tarangire-Manyara ecosystem, contrary to what has been found by other studies (Hockings et al., 2020; Waithaka et al., 2021; Walters et al., 2021) in various places around the world where poaching, deforestation, and other illegal activities are reported to increase during this juncture. The reason behind the minimal cases of poaching and other illegal issues may probably be an intensive and total focus, as well as a shift of most WMA's workers on patrols and protection of wildlife and WMA's boundaries during the COVID-19 pandemic, as reported by some leaders from the Burunge WMA Authority. The occurrence of COVID-19 has opened many wildlife sector authorities' and adjacent local communities' eyes to how prepared these sides should always be to minimize the effects of unanticipated disasters like COVID-19.

\subsection{Implication in biodiversity conservation}

COVID-19 has revealed the resilience level of most protected and conserved areas in Tanzania and worldwide. The COVID-19 outbreak has led to severe consequences for both protected areas and the local population, relying on numerous activities taking place alongside these areas. The study found that some individuals were employed in the tourism sector, while others were involved in different informal socioeconomic activities within and around the WMA to make a living (Shoo et al., 2021). The interruption of the tourism sector has thus caused considerable difficulties in dealing with various circumstances in protected areas and neighboring local people, which face numerous animal conservation challenges, particularly by delegating their plots of land for conservation and enduring several cases caused by wildlife in their communities. The findings of the study revealed that the shift of local communities to alternative forms of revenue signified the start of a new episode in wildlife protection, particularly after discovering that agriculture, fishing, and livestock keeping, among other things, were the most popular alternative means of income adopted by communities during the COVID-19 juncture. By examining the effects of these activities on natural ecosystems and the diversity of species (Seki et al., 2018), there is a need to develop a range of methodologies and tactics to mitigate their overall impact on biodiversity.

Page 19/28 
There is a very close link between local communities' livelihoods and protected areas (Figure 3). Once their sources of income get disrupted, the likelihood of invading and over-exploiting available resources becomes higher but dangerous for wildlife and future generation. According to Ellis (2000), there is a need for the local community to have a diverse source of income that is both socially and environmentally friendly, rather than relying only on tourists to avoid potential biodiversity damage.

\section{Conclusion And Recommendation}

The emergence of the COVID-19 pandemic has had a variety of negative implications in several sectors across the globe. The wildlife industry was also affected by COVID-19's potential consequences, with some operations inside protected areas and among participating communities being halted. The consequences of the COVID-19 pandemic were felt not only in the protected and conserved areas but also in the local communities surrounding these areas. The emergence of the COVID-19 pandemic has had a variety of negative implications in several sectors across the globe. Unreadiness to act immediately and effectively during the COVID-19 pandemic worsened the socioeconomic status of the indigenous and local communities due to the lack of diversified sources of income. For the sake of their lives, many individuals turned to agriculture, cattle rearing, and fishing as a survival strategy. Due to a lack of alternative sources of revenue, many individuals may become involved in illegal activities, such as poaching and deforestation which risk the sustainability of protected and conserved areas.

To mitigate the significant negative repercussions of unanticipated crises such as COVID-19 on local communities and biodiversity, it is proposed to encourage and assist indigenous and local people with diverse sources of income to lessen their total reliance on natural resources such as beekeeping and fish

farming and to adopt environmentally and socially friendly techniques of farming and fishing that will be more fruitful with very little strain on the natural habitat. Moreover, the protected and conserved areas authorities should encourage and promote local tourism to minimize the entire dependency on foreign tourists.

\section{Declarations}

\section{ACKNOWLEDGEMENT}

We acknowledge the technical support provided by the staff of the University of Dodoma and Burunge Wildlife Management Area Authority during data collection and report preparation.

\section{ETHICAL DECLARATION}

The University of Dodoma provided ethical clearance for this work, with reference number MA.84/261/02.

\section{INFORMED CONSENT}

Informed consent was obtained from individual participant included in the study.

\section{AVAILABILITY OF DATA AND MATERIALS}


Not applicable.

\section{CONSENT FOR PUBLICATION}

Not applicable.

\section{DECLARATION OF INTERESTS}

The authors declare that they have no known competing financial interests or personal relationships that could have appeared to influence the work reported in this paper.

\section{FUNDING SOURCE}

There is no any funding source.

\section{AUTHORS' CONTRIBUTION}

All authors were equally involved in analyzing and editing the paper. All authors read and approved the final manuscript.

\section{References}

African Union Commission. (2020). Impact of the Corona Virus (Covid 19) on the African Economy. Journal of Chemical Information and Modeling, 53(9), 1689-1699.

Attah, A. N. (2021). Initial Assessment of the Impact of COVID-19 on Sustainable Forest Management African States. United Nations Forum on Forests Secretariat, April.

Bennett, N. J., Finkbeiner, E. M., Ban, N. C., Belhabib, D., Jupiter, S. D., Kittinger, J. N., Mangubhai, S., Scholtens, J., Gill, D., \& Christie, P. (2020). The COVID-19 Pandemic, Small-Scale Fisheries and Coastal Fishing Communities. Coastal Management, 48(4), 336-347.

https://doi.org/10.1080/08920753.2020.1766937

Ellis, F. (2000). Rural livelihoods and Diversity in Developing Countries. OUP Oxford, 2000.

FAO. (2020). COVID-19 global economic recession: Avoiding hunger must be at the centre of the economic stimulus. https://doi.org/10.4060/ca8800en

George, G., Kotha, R., Parikh, P., Alnuaimi, T., \& Bahaj, A. S. (2016). Social structure, reasonable gain, and entrepreneurship in Africa. Strategic Management Journal, 37(6), 1118-1131.

https://doi.org/10.1002/smj.2381

Hockings, M., Dudley, N., Elliott, W., Ferreira, M. N., Mackinnon, K., Pasha, M. K. S., Phillips, A., Stolton, S., Woodley, S., Appleton, M., Chassot, O., Fitzsimons, J., Galliers, C., Kroner, R. G., Goodrich, J., Hopkins, J., 
Jackson, W., Jonas, H., Long, B., ... Yang, A. (2020). Editorial essay: Covid-19 and protected and conserved areas. Parks, 26(1). https://doi.org/10.2305/IUCN.CH.2020.PARKS-26-1MH.en

Kaswamila, A. (2009). Human-wildlife conflicts in monduli District, Tanzania. International Journal of Biodiversity Science and Management, 5(4). https://doi.org/10.1080/17451590903557526

Kaswamila, A. (2012). An Analysis of the Contribution of Community Wildlife Management Areas on Livelihood in Tanzania. In Sustainable Natural Resources Management. https://doi.org/10.5772/32987

Khan, K., Kunz, R., Kleijnen, J., \& Antes, G. (2003). RESEARCH METHODOLOGY Five steps to conducting a systematic review. Journal of the Royal Society of Medicine, 96(3), 118-121.

Kideghesho, J. R., Kimaro, H. S., Mayengo, G., \& Kisingo, A. W. (2021). Will Tanzania's Wildlife Sector Survive the COVID-19 Pandemic? In Tropical Conservation Science (Vol. 14).

https://doi.org/10.1177/19400829211012682

Kiffner, C., Thomas, S., Speaker, T., O'Connor, V., Schwarz, P., Kioko, J., \& Kissui, B. (2020). Communitybased wildlife management area supports similar mammal species richness and densities compared to a national park. Ecology and Evolution, 10(1). https://doi.org/10.1002/ece3.5916

Knapp, E. J. (2012). Why poaching pays: A summary of risks and benefits illegal hunters face in Western Serengeti, Tanzania. Tropical Conservation Science, 5(4), 434-445.

https://doi.org/10.1177/194008291200500403

Komba, A. W., Watanabe, T., Kaneko, M., \& Chand, M. B. (2021). Monitoring of vegetation disturbance around protected areas in central tanzania using landsat time-series data. Remote Sensing, 13(9), 1-18. https://doi.org/10.3390/rs13091800

Loibooki, M., Hofer, H., Campbell, K. L. I., \& East, M. L. (2002). Bushmeat hunting by communities adjacent to the Serengeti National Park, Tanzania: The importance of livestock ownership and alternative sources of protein and income. Environmental Conservation, 29(3), 391-398. https://doi.org/10.1017/S0376892902000279

Manenti, R., Mori, E., Di Canio, V., Mercurio, S., Picone, M., Caffi, M., Brambilla, M., Ficetola, G. F., \& Rubolini, D. (2020). The good, the bad and the ugly of COVID-19 lockdown effects on wildlife conservation: Insights from the first European locked down country. In Biological Conservation (Vol. 249). https://doi.org/10.1016/j.biocon.2020.108728

McDonagh, M. S., Whiting, P. F., Wilson, P. M., Sutton, A. J., Chestnutt, I., Cooper, J., Misso, K., Bradley, M., Treasure, E., \& Kleijnen, J. (2000). Systematic review of water fluoridation. BMJ (Clinical Research Ed.), 321(7265), 855-859. https://doi.org/10.1136/bmj.321.7265.855

Mmbaga, N.E, Munishi, L. ., \& Treydte, A. . (2017). How dynamics and drivers of land use/land cover change impact elephant conservation and agricultural livelihood development in Rombo, Tanzania. 
Journal of Land Use Science, 12(2), 168-181.

Mmbaga, Naza E., Munishi, L. K., \& Treydte, A. C. (2021). Cropping patterns along an altitudinal gradient and their implications to wildlife conservation in Rombo, Tanzania. Global Ecology and Conservation, 28(June), e01683. https://doi.org/10.1016/j.gecco.2021.e01683

Morar, F., \& Peterlicean, A. (2012). The Role and Importance of Educating Youth Regarding Biodiversity Conservation in Protected Natural Areas. Procedia Economics and Finance, 3(12), 1117-1121. https://doi.org/10.1016/s2212-5671(12)00283-3

Moshi, B. S. (2016). Impacts of Protected Areas on Local Livelihood: a Case Study of. July, 44.

Nadeson, T., \& Barton, M. (2014). The Role of Youth in the Conservation of Biodiversity: WWF-Malaysia's Experiences. Population, 15(40), 6-13.

Neupane, D. (2020). How conservation will be impacted in the COVID-19 pandemic. Wildlife Biology, 2020(2). https://doi.org/10.2981/wlb.00727

Ngongolo, K. (2020). Influence of cattle movement, ecological and risk factors on trypanosome infections of cattle in Simanjiro and Monduli districts, Tanzania.

NIST. (2020). Selecting Sample Sizes. Engineering statistic handbook. NIST an Agency of the U.S. Department of Commerce.

Nyomi, E. (2020). A Reflection on World Environment Day: Is There Really A Silver Lining for Nature Amidst This Pandemic? https://www.wabicc.org/a-reflection-on-world-environment-day-is-there-really-asilver-lining-for-nature-amidst-this-pandemic/

Pinner, D., Rogers, M., \& Samandari, H. (2020). Addressing Climate Change in a Post-Pandemic World. McKinsey Quarterly, April, 1-6. https://www.mckinsey.com/ /media/McKinsey/Business Functions/Sustainability/Our Insights/Addressing climate change in a post pandemic world/Addressingclimate-change-in-a-post-pandemic-world-v3.ashx

Rulli, M. (2020). Experts in Kenya fear poaching, deforestation are surging during COVID-19 lockdown. https://abcnews.go.com/International/experts-kenya-fear-poaching-deforestation-surginglockdown/story?id=70500218

Saadat, S., Rawtani, D., \& Hussain, C. M. (2020). Environmental perspective of COVID-19. Science of the Total Environment, 728, 138870. https://doi.org/10.1016/j.scitotenv.2020.138870

Safaribookings.com. (2021). The Impact of the coronavi- rus pandemic on the safari industry. https://www.safaribookings.com/blog/coronavirus-outbreak 
Seki, H. A., Shirima, D. D., Courtney Mustaphi, C. J., Marchant, R., \& Munishi, P. K. T. (2018). The impact of land use and land cover change on biodiversity within and adjacent to Kibasira Swamp in Kilombero Valley, Tanzania. African Journal of Ecology, 56(3), 518-527. https://doi.org/10.1111/aje.12488

Shoo, R. A., Mtui, E. ., Kimaro, J. ., Kinabo, N. ., Lendii, G. ., \& Kideghesho, J. . (2021). Wildlife Management Areas in Tanzania: Vulnerability and Survival Amidst COVID-19. In Managing Wildlife in a Changing World [Working Title]. https://doi.org/10.5772/intechopen.97396

Sigala, A., Ngongolo, K., \& Mmbaga, N. (2021). Awareness and involvement of local communities adjacent Kihansi catchment in conservation of the re-introduced Kihansi spray toads (Nectophrynoides asperginis). Global Ecology and Conservation, 31(October), e01861. https://doi.org/10.1016/j.gecco.2021.e01861

Spenceley, A., McCool, S., Newsome, D., Báez, A., Barborak, J. R., Blye, C. J., Bricker, K., Cahyadi, H. S., Corrigan, K., Halpenny, E., Hvenegaard, G., King, D. M., Leung, Y. F., Mandić, A., Naidoo, R., Rüede, D., Sano, J., Sarhan, M., Santamaria, V., ... Zschiegner, A. K. (2021). Tourism in protected and conserved areas amid the covid-19 pandemic. Parks, 27(Special Issue). https://doi.org/10.2305/IUCN.CH.2021.PARKS-27SIAS.en

UNDP. (2020). Socia-economic impact of Covid-19 on the people of Uganda. In UNDP (Vol. 148).

UNWTO. (2020a). Impact assessment of the COVID-19 outbreak on international tourism. UGC Care Group I Listed Journal, 10(6), 148-159. http://www.junikhyat.com/no_1_jun_20/18.pdf?i=1

UNWTO. (2020b). International Tourist Arrivals Could Fall By 20-30\% in 2020. Unwto. Org, 34, 33-34. https://www.unwto.org/news/international-tourism-arrivals-could-fall-in-2020

UNWTO. (2020c). International Tourist Numbers Could Fall 60-80\% in 2020. UNWTO Reports. https://en.travel2latam.com/nota/60051-international-tourist-numbers-could-fall-60-80-in-2020according-unwto

URT. (2006). United Republic of Tanzania, National Population Policy. Ministry of planning Economy and Empowerment. 4(3), 235-245.

Waithaka, J., Dudley, N., Álvarez Malvido, M., Mora, S. A., Chapman, S., Figgis, P., Fitzsimons, J., Gallon, S., Gray, T. N. E., Kim, M., Pasha, M. K. S., Perkin, S., Roig-Boixeda, P., Sierra, C., Valverde, A., \& Wong, M. (2021). Impacts of COVID-19 on protected and conserved areas: A global overview and regional perspectives. Parks, 27(Special Issue). https://doi.org/10.2305/IUCN.CH.2021.PARKS-27-SIJW.en

Walters, G., Broome, N. P., Cracco, M., Dash, T., Dudley, N., Elías, S., Hymas, O., Mangubhai, S., Mohan, V., Niederberger, T., Kema, C. A. N. K., Lio, A. O., Raveloson, N., Rubis, J., Toviehou, S. A. R. M., \& Vliet, N. Van. (2021). COVID-19, indigenous peoples, local communities and natural resource governance. Parks, 27(Special Issue). https://doi.org/10.2305/IUCN.CH.2021.PARKS-27-SIGW.en 
Wang, C., Horby, P. W., Hayden, F. G., \& Gao, G. F. (2020). A novel coronavirus outbreak of global health concern. The Lancet, 395(10223), 470-473. https://doi.org/10.1016/S0140-6736(20)30185-9

World Bank. (2020). COVID-19 (Coronavirus) Drives Sub-Saharan Africa Toward First Recession in 25 Years. Www.Worldbank.Org.

WWF. (2014). Tanzania 's Wildlife Management Areas. A 2012 Status Report. 1-70.

\section{Figures}

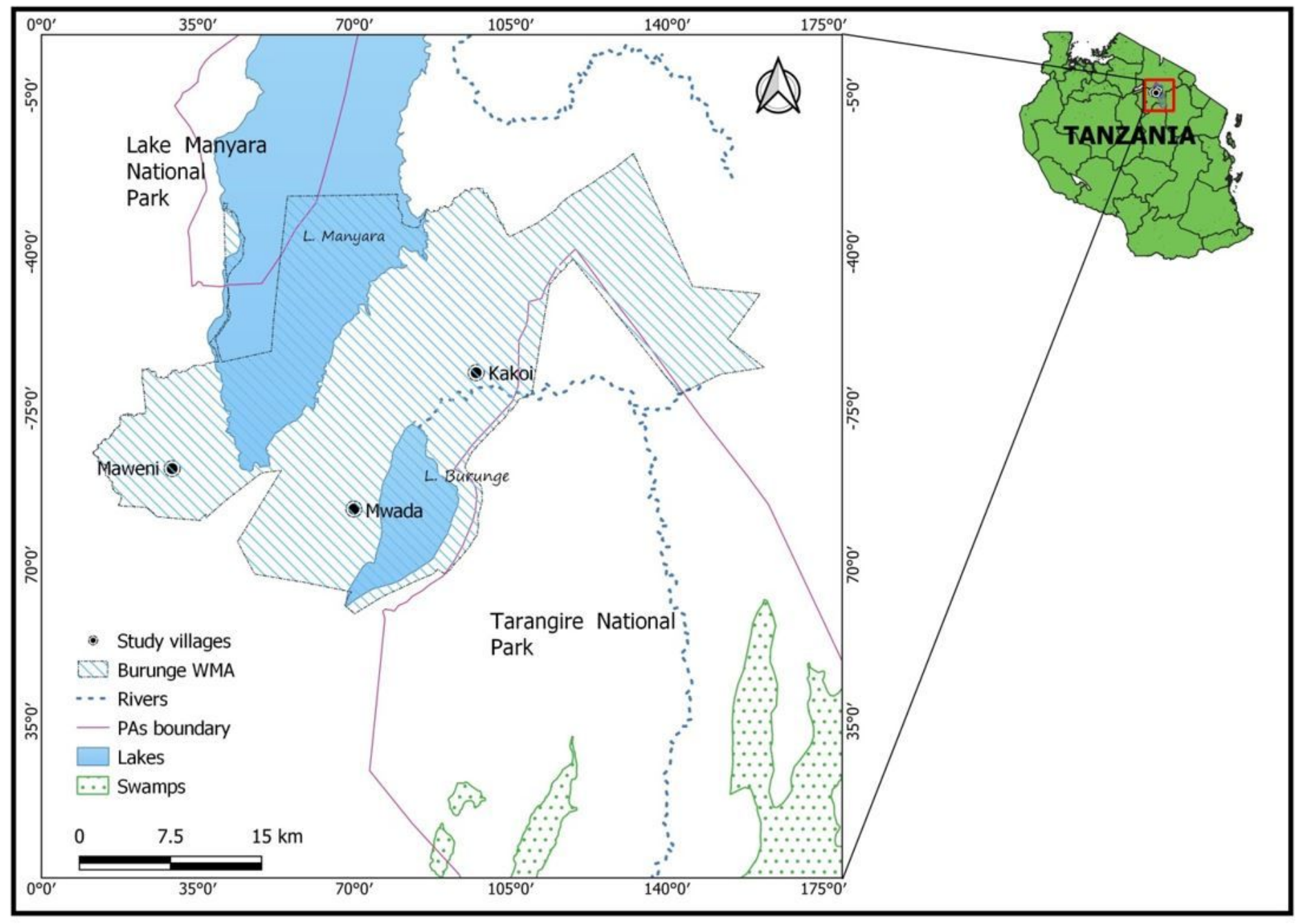

Figure 1

A map of the three study villages (Kakoi, Maweni and Mwada) within the Burunge

Wildlife Management Area (WMA) in the Tarangire-Manyara Ecosystem (TME)

Note: PAs - Protected Areas 


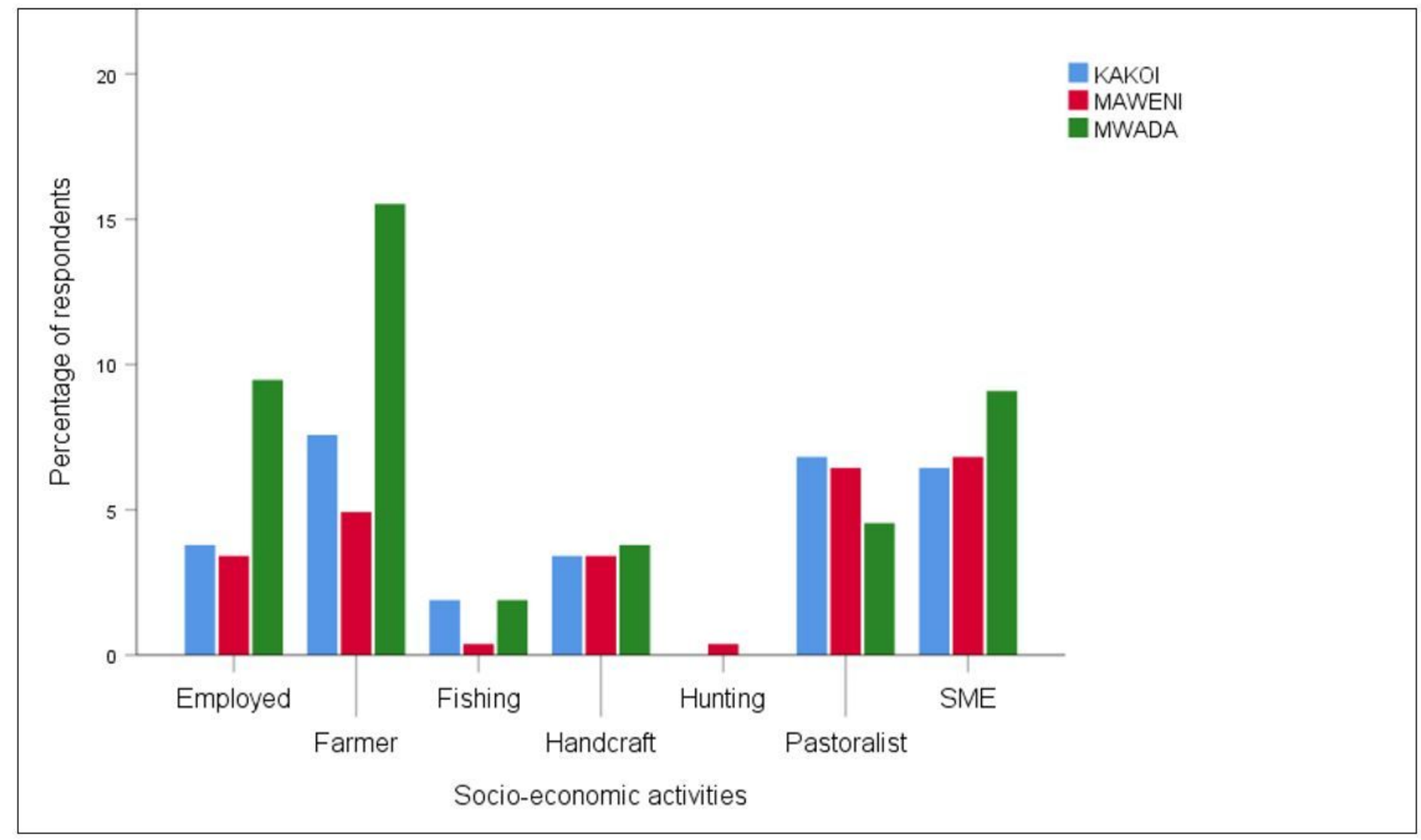

Figure 2

Socio-economic activities of respondents in the three study areas (Kakoi, Maweni, and

Mwada)

Note: SME - Small-to-medium enterprises 


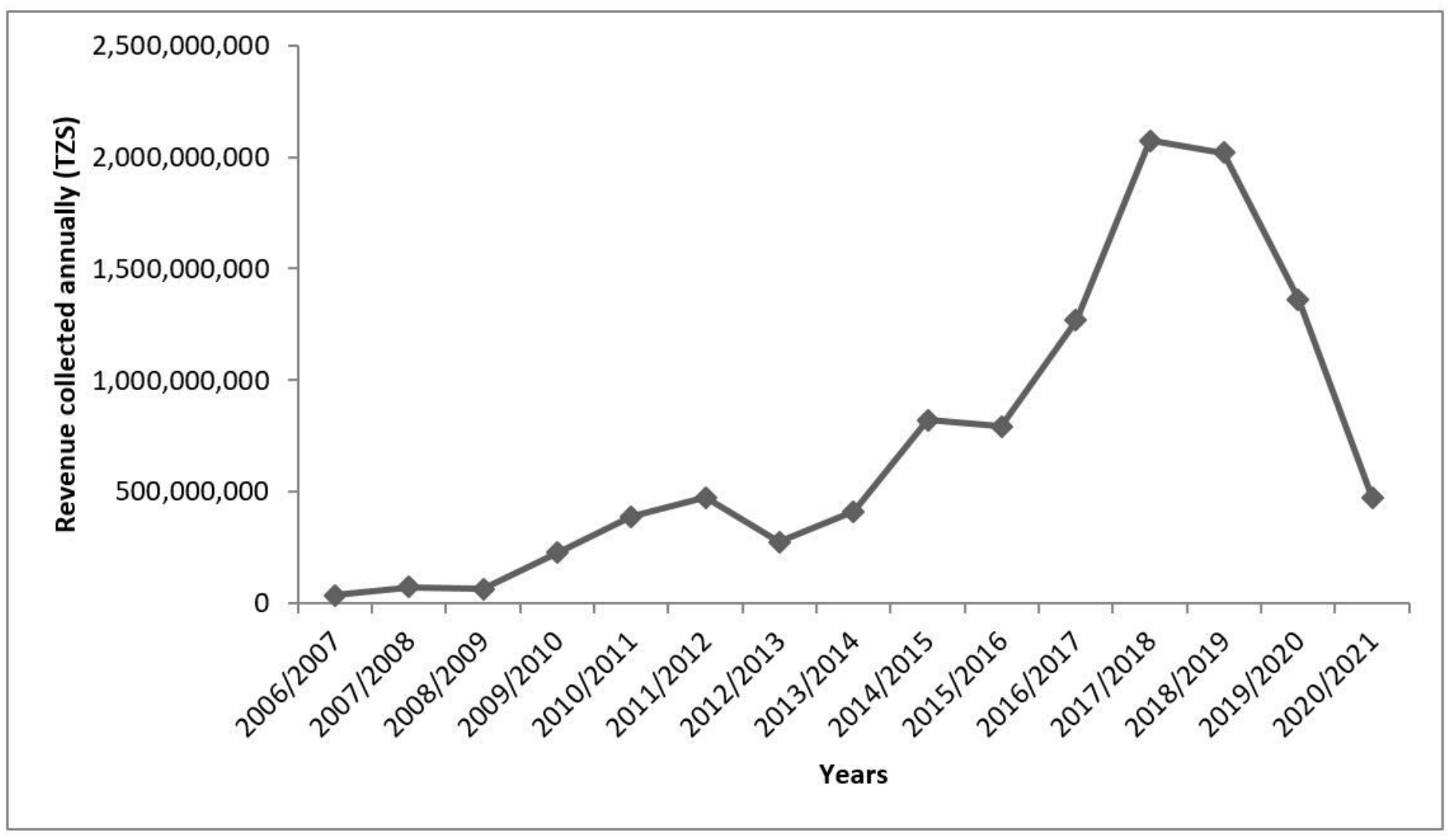

\section{Figure 3}

Burunge WMA' revenue collection trend over several years before (2006-2018) and during COVID-19 pandemic (2019-2021) 


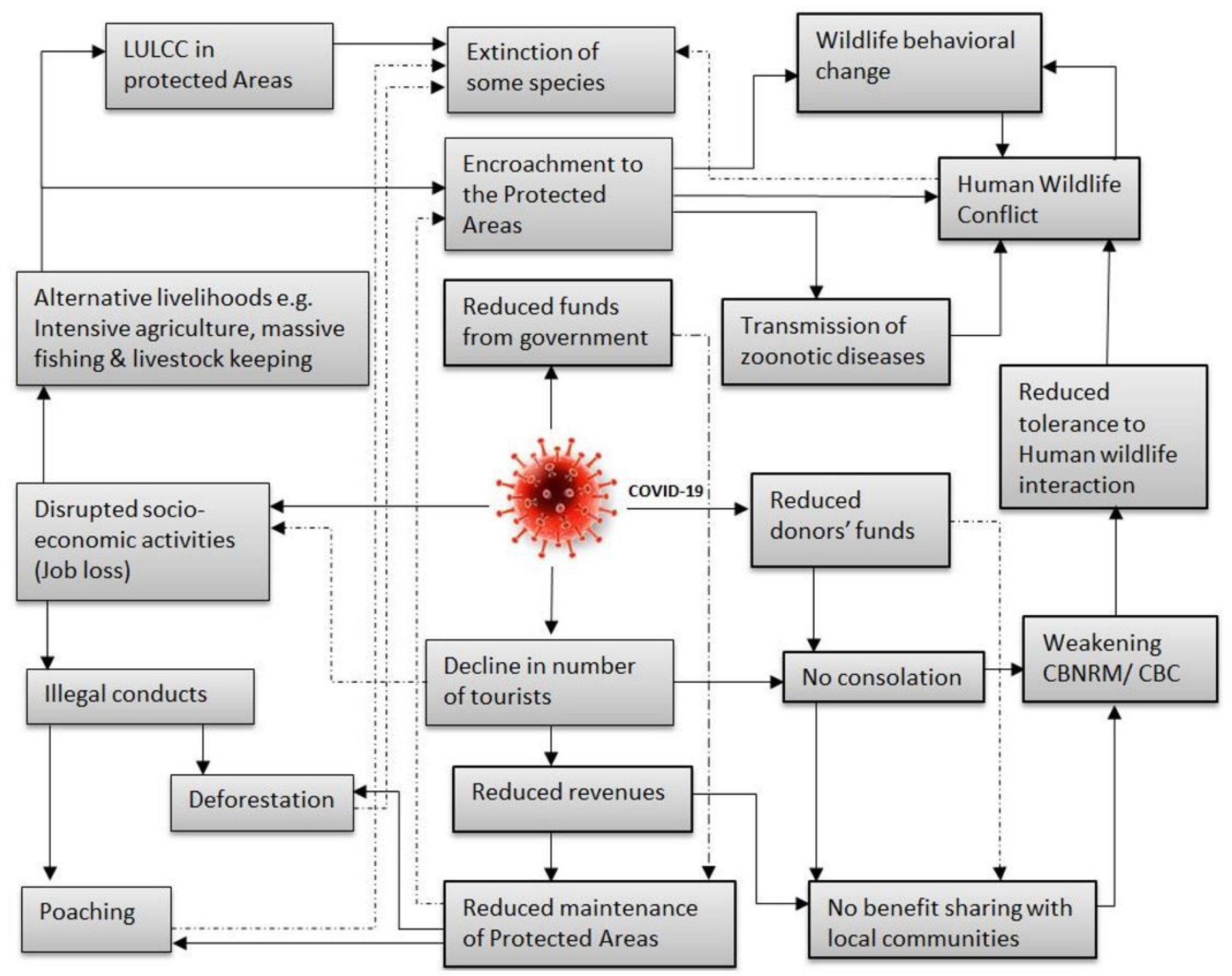

\section{Figure 4}

The conceptual direct and indirect effects of COVID-19 as related to the local communities livelihoods and biodiversity conservation (a close linkage between)

Note: LULCC - Land use land cover change, CBNRM - Community based natural resource management, $\mathrm{CBC}$ - Community based conservation 